\title{
SEBARAN DAN KEPADATAN BURUNG TEKUKUR DI PULAU KISAR KABUPATEN MALUKU BARAT DAYA KECAMATAN KISAR UTARA
}

\author{
Ona Cornelis', Ali Awan ${ }^{2}$ \\ 1Alumi Program Studi Pendidikan Biologi \\ ${ }^{2}$ Program Studi Pendidikan Biologi
}

E-mail: aliawanprof@gmail.com

\begin{abstract}
Background: Birds are part of biodiversity that must be preserved from extinction and decrease in species diversity. This study aims to determine the density and distribution of Tekukur birds in the North of Lebelau, Nomaha and Purpura Villages, Kisar District, Southwest Maluku Regency.

Method: This study used a descriptive survey method in three locations namely Lebelau, Nomaha and Purpura Villages. At each research location taken in the plantation area, bushes and trees.

Result: Based on the research that has been done in Lebelau, Nomaha and Purpura villages, the density values range between 76.6 ind / $\mathrm{KM}^{2}-96.6$ ind / $\mathrm{KM}$, which shows that the highest density is in Lebelau village with a density value of 96.6 ind $/ \mathrm{KM}^{2}$, and the lowest is in Purpura Village with a density of 76.6 ind / $\mathrm{KM}^{2}$,

Conclusion: Distribution patterns in Lebelau, Pupura and Nomaha Villages include evenly distributed distribution patterns.
\end{abstract}

Keywords: Distribution, density, bird Tekukur

\begin{abstract}
Abstrak
Latar Belakang: Burung adalah bagian dari keanekaragaman hayati yang harus dijaga kelestariaannya dari kepunahan maupun penurunan keanekaragaman jenisnya. Penelitian ini bertujuan untuk mengetahui kepadatan dan sebaran burung Tekukur di Utara Desa Lebelau, Nomaha dan Purpura, Kecamatan Kisar, Kabupaten Maluku Barat Daya.

Metode: Penelitian ini menggunakan metode deskriptif survey di tiga lokasi yaitu Desa Lebelau, Nomaha dan Purpura. Pada setiap lokasi penelitian yang di ambil di area perkebunan, semak-semak dan pepohonan.

Hasil: Berdasarkan penelitian yang telah dilakukan di desa Lebelau, Nomaha dan Purpura di dapatkan nilai kepadatan berkisar diantara 76,6 ind//KM²-96,6 ind/KM, dimana terlihat bahwa kepadatan tertinggi berada di desa Lebelau dengan nilai kepadatan $96,6 \mathrm{ind} / \mathrm{KM}^{2}$, dan yang paling rendah terdapat di Desa Purpura dengan nilai kepadatan 76,6 ind $/ \mathrm{KM}^{2}$,

Kesimpulan: Pola penyebaran di Desa Lebelau, Pupura dan Nomaha termasuk pola penyebaran tersebar merata.
\end{abstract}

Kata kunci: Sebaran, kepadatan, burung Tekukur 


\section{PENDAHULUAN}

Indonesia merupakan Negara kepulauan yang memiliki kekayaan alam sangat besar baik lautan maupun daratan yaitu berbagai jenis hewan dan tumbuhan. Di daratan terdapat banyak jenis hewan diantaranya jenis burung yang terdapat kurang lebih 1500 jenis yang tersebar di dalam wilayah oriental (Asia), wilayah wallacea adalah kawasan campuran yang sangat khas dan zona peralihan dari Avifauna oriental dan Australia - Papua. Wilayah Wallacea meliputi Sulawesi, Nusa tengggara dan Maluku. Menurut perkiraan para ahli sekitar 700 jenis spesies burung dan di antaranya 249 jenis burung endemik terdapat pada kawasan Wallacea (Coates dan Bioshop, 2000).

Burung adalah satwa liar yang memiliki kemampuan hidup di hampir semua tipe habitat, dari kutub sampai gurun, dari hutan konifer sampai hutan tropis, dari sungai, rawa-rawa sampai lautan. Burung mempunyai mobilitas yang tinggi dan kemampuan beradaptasi terhadap berbagai tipe habitat yang luas (Welty 1982). Salah satu tipe ekosistem yang digunakan oleh burung adalah hutan tanaman (Alikodra 2002) yang merupakan bentuk habitat baru yang berbeda dengan kondisi sebelumnya. Hutan tanaman hanya berupa tegakan vegetasi tanaman sejenis (monokultur), dan adanya dominasi campur tangan manusia di dalamnya menyebabkan keadaan tingkat keragaman jenis yang rendah dan ketidakseimbangan keadaan faktor-faktor lingkungan di hutan tanaman (Djunaidah 1994). Berbeda dengan hutan alam yang terdiri atas berbagai jenis vegetasi dan strata sehingga hutan alam memiliki keanekaragaman jenis yang tinggi. Hutan tanaman merupakan salah satu kawasan budidaya yang umumnya memiliki keanekaragaman yang rendah dan seragam (Gani 1993).

Burung adalah bagian dari keanekaragaman hayati yang harus dijaga kelestariaannya dari kepunahan maupun penurunan keanekaragaman jenisnya. Burung memiliki banyak manfaat dan fungsi bagi manusia, baik secara langsung maupun tidak langsung. Manfaat dan fungsi burung secara garis besar dapat digolongkan dalam nilai budaya, estetik, ekologis, ilmu pengetahuan dan ekonomis
(Yuda 1995). Alikodra (2002) dan Ontario et al. (1990) menambahkan bahwa burung memiliki peranan penting dari segi penelitian, pendidikan, dan untuk kepentingan rekreasi dan pariwisata. Manfaat dan fungsi burung yang begitu besar bagi kehidupan manusia, sehingga mendorong upaya untuk menjaga kelestarian dan keanekaragamannya. Namun akhir-akhir ini kehidupan burung semakin lama semakin terdesak yang sebagian besar disebabkan oleh manusia dengan merusak dan mengubah fungsi habitat burung. Kegiatan tersebut antara lain dengan konversi lahan untuk pemukiman, peternakan, perkebunan, perindustrian, pertambangan dan lainnya. Kegiatan-kegiatan tersebut membutuhkan lahan yang cukup luas, sehingga habitat burung semakin berkurang dengan bertambahnya kegiatan yang dilakukan oleh manusia untuk memenuhi kebutuhan hidupnya.Kegiatan-kegiatan tersebut dapat menyebabkan kepunahan yang melampaui tingkat pengembaliannya (Primack et al. 1998).

\section{MATERI DAN METODE}

Penelitian menggunakan penelitian survey yaitu penelitian yang dilakukan pada populasi besar maupun kecil, tetapi data yang dipelajari adalah data dari sampel yang diambil dari populasi tersebut, sehingga ditemukan kejadian-kejadian relatif distribusi, dan hubungan antar variabel. sosiologi maupun psikologis.

\section{HASIL DAN PEMBAHASAN \\ Kepadatan Burung Tekukur}

Hasil kepadatan Burung Tekukur di Kecamata Kisar Utara dapat dilihat pada tabel berikut.

\section{Tabel 1. Kepadatan Burung Tekukur Di Kecamata Kisar Utara.}

\begin{tabular}{clc}
\hline No & Nama desa & Kepadatan \\
\hline 1 & Lebelau & $96,6 \mathrm{ind} / \mathrm{km}^{2}$ \\
2 & Nomaha & $80 \mathrm{ind} / \mathrm{km}^{2}$ \\
3 & Pur-pura & $76,6 \mathrm{ind} / \mathrm{km}^{2}$ \\
\hline
\end{tabular}

Berdasarkan penelitian yang telah dilakukan di desa Lebelau, Nomaha dan 
Pur-pura di dapatkan nilai kepadatan berkisar diantara 76,6 ind/KM²-96,6 ind/KM, dimana terlihat bahwa kepadatan tertinggi berada di desa Leblau dengan nilai kepadatan 96,6 ind $/ \mathrm{KM}^{2}$, dan yang ke dua berada pada desa Nomaha dengan nilai kepadatan 80 ind $/ \mathrm{KM}^{2}$, dan paling rendah berada di desa Pur-pura dengan nilai kepadatan 76 ind $/ \mathrm{KM}^{2}$.

\section{Pola Sebaran}

Pola sebaran didesa Lebelau, desa Nomaha, dan desa Pur-pura dihitung dengan rumus morisita di mana hasil perhitungannya sebagai berikut.

Tabel 2. Hasil Perhitungan Sebaran Burung Tekukur

\begin{tabular}{ccccc}
\hline Ulangan & Lebelau & Nomaha & Purpura & $\Sigma$ \\
\hline 1 & 5 & 5 & 7 & 17 \\
2 & 6 & 6 & 6 & 18 \\
3 & 5 & 5 & 2 & 12 \\
4 & 7 & 4 & 3 & 14 \\
5 & 6 & 4 & 5 & 15 \\
$\Sigma$ & 29 & 24 & 23 & 76 \\
Rata-rata & $\mathbf{5 , 8}$ & $\mathbf{4 , 8}$ & $\mathbf{4 , 6}$ &
\end{tabular}

$$
\begin{aligned}
& \text { Keterangan: } \\
& \sum x 1=29 . \sum x 3=23 . n=5 . n=76 . \sum \times 2=24 \\
& \text { Id Lebelau }=n \sum x 1-N \frac{-N \sum x 1^{2}-N}{N(N-1)}=5 \frac{(29)^{2}-76}{76(76-1)}=0,724 \\
& \text { Id Nomaha }=n \sum x 2-N \frac{-N \sum x 1^{2}-N}{N(N-1)}=5 \frac{(24)^{2}-76}{76(76-1)}=0,492 \\
& \text { Id Purpura }=n \sum x 3-N \frac{-N \sum x 1^{2}-N}{N(N-1)}=5 \frac{(23)^{2}-76}{76(76-1)}=0,451
\end{aligned}
$$

Berdasarkan hasil Sebaran pada tabel 2 dapat dilihat bahwa dari hasil penjeratan yang dilakukan bahwa burung Tekukur yang ditemukan satu hari didesa Lebelau paling sedikit 5 ekor dan paling banyak 7 ekor, untuk desa Nomaha paling sedikit 4 ekor dan yang paling banyak 6 dan untuk desa Pur-pura paling sedikit 2 ekor dan yang paling banyak 7 ekor. Ini menunjukan bahwa setiap harinya burung Tekukur masih dapat ditemukan dalam jeratan yaitu 29 ekor. Sedangkan untuk desa Nomaha dan Lebelau masing-masing sebanyak 24 dan 23 ekor burung Tekukur dengan ratarata masing-masing burung yang ditemukan di desa Lebelau, Nomaha dan Pur-pura sebesar 5,8 4,8 dan 4,6. Pola penyebaran dihitung menggunakan rumus moristia dimana diketahui nilai total individu sebesar 76, total individu setiap desa masingmasing sebesar 29, 24 dan 23 ekor burung Tekukur dengan total pengulangan 5 kali, hasil perhitungan di atas dapat dilihat lebih jelas pada pada tabel 3 .

Dari hasil penelitian yang telah dilakukan tentang Sebaran dan Kepadatan burung Tekukur di pulau Kisar dapat dilihat pada tabel di bawah ini.

\section{Data Hasil Sebaran Burung Tekukur}

Hasil Sebaran burung Tekukur Di Kecamatan Kisar Utara dapat dilihat pada tabel 3 berikut.

\section{Tabel 3. Hasil Sebaran burung Tekukur Di Kecamatan Kisar Utara.}

\begin{tabular}{cccc}
\hline No & $\begin{array}{c}\text { Nama } \\
\text { Desa }\end{array}$ & Sebaran & $\begin{array}{c}\text { Pola } \\
\text { sebaran }\end{array}$ \\
\hline 1 & Lebelau & 0,724 & Seragam \\
2 & Nomaha & 0,492 & Seragam \\
3 & Pur-pura & 0,451 & Seragam \\
\hline
\end{tabular}

Burung Tekukur merupakan burung yang memiliki suhu tubuh yang tinggi dan kebutuhan makanannya sangat banyak (Ensiklopedia Indonesia, 1992; Darmawan, 2006). Burung Tekukur di desa Lebelau lebih banyak dibandingkan dengan jumlah burung Tekukur desa Nomaha dan Purpura karena desa ini memiliki lahan dan luas daerah yang cukup besar dan jumlah makanan Tekukur yang paling banyak dan 
banyak pepohonan di bandingkan ke dua desa tersebut. Dapat dilihat pada gambar.

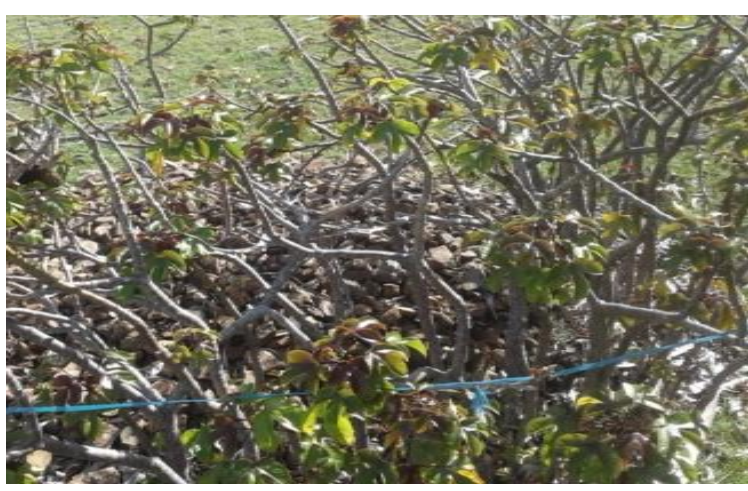

Gambar 1. Area Semak

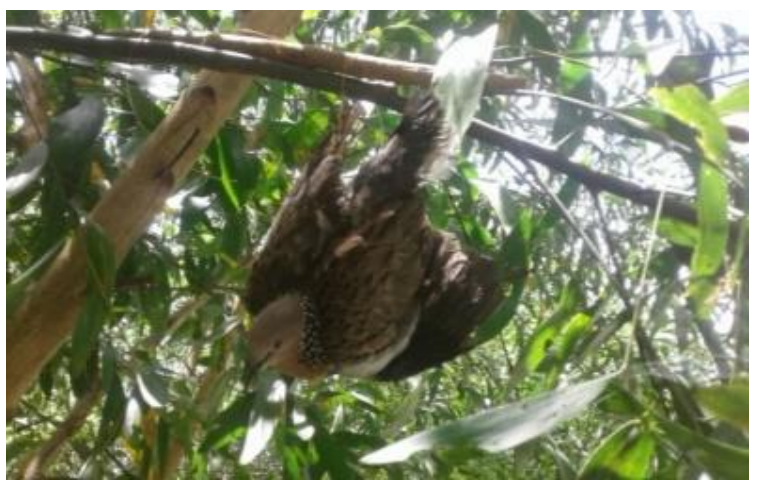

Gambar 2. Area Pepohonan

Sebelum melakukan penjeratan, telah di lakukan survei tempat yang khususnya biasanya burung tekukur sering beraktifitas. Di dalam proses penjeratan tidak ada burung selain burung Tekukur yang terjerat karena tempat yang sudah di tempati burung ini tidak ada lagi burung lain yang bisa menempati daerah tersebut. Burung ini mempunyai kecenderungan menjadi pemberang dan mengusir burung lain dari sekitar sarang atau wilayahnya (Soejoedono 2001. Burung memiliki suhu tubuh yang tinggi dan kebutuhan makanannya sangat banyak (Ensiklopedia Indonesia, 1992; Darmawan, 2006).

Titik pengamatan masing masing stasiun berjumlah 7 setiap 2 hari sekali dan 5 kali pengulangan selama 4 minggu dan pendataan terus berlangsung. Waktu pemasangan jerat sekitar pukul 06.00 WIT. Berdasarkan penelitian yang diperoleh diketahui nilai kepadatan burung di masing masing lokasi Desa lebelau sebesar 96,6ind $/ \mathrm{km}^{2}$,di desa Pur-pura sebesar 76,6 ind $/ \mathrm{km}^{2}$, dan di desa Nomaha sebesar 80 ind $/ \mathrm{km}^{2}$. Dari ketiga desa tersebut, jumlah terbanyak terdapat pada desa Lebelau karena di sana terdapat banyak area pepohonan. Hal ini dikarenakan habitat pepohonan merupakan tempat efektif burung yang berupa tempat tinggal. Berdasarkan penelitian yang di lakukan serta dengan melakukan pengolahan data maka hasil sebaran yang didapatkan dari Desa Lebelau sebesar 0,765, Nomaha sebesar 0,59 dan Purpura 0,475 berdasarkan hasil tersebut dapat di simpulkan bahwa tingkat penyebaran burung tekukur tertinggi berada pada desa Lebelau, hal ini di sebabkan oleh besarnya lingkungan yang tenang dan terhindar dari gangguan manusia serta banyaknya area pepohonan serta jumlah pasokan makanan untuk burung jenis ini lebih banyak. Selanjutnya untuk pola sebaran terendah berada pada desa purpura yang mana kita ketahui bahwa pada lokasi ini terjadinya pola penyebaran terendah dikarenakan faktor lingkungan manusia yang begitu besar kemudian kurangnya pasokan bahan makanan di desa purpura ini serta kurangnya area pepohonan. Sedangkan untuk desa Nomaha dapat kita lihat bahwa desa ini memiliki tingkat penyebaran yang normal hal ini di karenakan luasnya lingkungan manusia yang beraktifitas tidak terlalu banyak dan jumlah pepohonan yang masi relatif banyak.sehingga sebaran burung tekukur di daerah ini tidak terlalu banyak dan tidak terlalu sedikit. Hal ini sejalan dengan teori yang mengatakan bahwa menurut Budiman (1991) bahwa kekayaan jenis Mollusca disuatu habitat sangat bergantung pada kemampuan jenis untuk beradaptasi terhadap kondisi lokal dan jumlah tipe habitat. Kariono et al., (2013) di dalam ekosistem yang dapat mengakomodasi jenis untuk hidup baik.

Perilaku datang dan perginya burung tekukur yang ada pada lokasi penelitian di kecamatan kisar utara ini dapat dikatakan bahwa sikap dri burung ini pada dasarnya dia tidak menetap pada suatu wilayah saja burung ini dapat datang dan pergi kapan saja dimana ia mau hal ini di sebabkan karena faktor makanan dan juga tempat tinggal burung ini. pada saat mengalami kehausan burung ini keluar dan mencari air untuk diminum. Pada perilaku istirahat burung ini, kebanyakan di temukan oleh 
peneliti bahwa, jenis burung ini sering beristirahat pada daerah pepohonan Akasia, karena jenis pohon akasia ini memiliki biji bijian yang dapat di makan oleh burung ini. Dalam proses pencarian makan juga, burung ini senantiasa melakukan pencarian makan yang tidak menetap. Burung ini mencari makan berpindahpindah karena pada setia lokasi atau wilayah penelitian yang di teliti tidak semuanya memiliki cadangan makanan yang banyak burung ini saat mencari makan terkadang pada waktu udarah matahari semakin panas dan ia berpindah tempat ke daerah lain untuk bertelur jenis burung ini kadang melakukan proses bertelur di lokasi yang kurang akan penduduk sehingga telur dari burung ini dapat terlindungi.

\section{KESIMPULAN}

Berdasarkan penelitian yang telah dilakukan dapat disimpulkan bahwa Pola penyebaran di desa Lebelau, Pupura dan Nomaha termasuk pola penyebaran tersebar merata.
DAFTAR PUSTAKA

Alikodra, 2002. Biologi Merupakan IImu Yang Mempelajari Tentang Makhluk Hidup. Jakarta: Erlangga.

Bioshop, 2000. Habitat burung di Indonesia. Jakarta: Rineka Cipta.

Budiman 1991. Mollusca. Bandung: Remaja Rosda Karya.

Coates, 2000. Habitat burung di Indonesia Jakarta: Rineka Cipta.

Djunaidah, 1994. Hakikat Peyebaran hewan Biologi di SMA. Jakarta: Erlangga.

Darmawan, 2006. Habitat Burung. Jakarta: Erlangga.

Gani, 1993. Hakikat Kepadatan Hewan, Jakarta: Bumi Aksara.

Ontario 1990. Jenis Burung di Indonesia. Jakarta: Erlangga

Primack, 1998. Burung di Indonesia Jakarta: Bumi Aksara.

Soejoedono, 2001. Habitat Burung. Jakarta Erlangga.

Welty, 2009. Proses Sebaran Hewan. Bandung: Bumi Aksara.

Yuda, 1995. Manfaat-manfaat Burung. Jakarta: Rineka Cipta. 